\title{
Development of Mathematics Teaching Device Integrated with Quranic Values: Issues, Challenges, and Implementation Model
}

\author{
Widodo Winarso ${ }^{1}$ \\ Institut Agama Islam Negeri Syekh Nurjati Cirebon, Indonesia \\ https://orcid.org/0000-0002-8527-7660 \\ Sirojudin Wahid \\ Institut Agama Islam Negeri Syekh Nurjati Cirebon, Indonesia \\ https:// orcid.org/0000-0002-0468-1574
}

\begin{abstract}
The purpose of this study was to develop an integrated mathematics teaching device with Quranic values that meet valid, practical, and effective criteria to meet good product standards. This study includes a development study consisting of the design and implementation phases. The analysis in this study used validity analysis with Aiken's validity index, and the utility analysis performed by transforming the results of the test data on five Widoyoko scales. The analysis required to test the effectiveness of the integrated mathematics teaching device with Quranic values uses a one-way ANOVA F test and a follow-up test using Post Hoc Multiple Comparisons. The results of verification by two experts stated that the Quranic values of the integrated mathematics teaching device met valid criteria. In line with the teacher's assessment that the four components evaluated, namely syllabus, lesson plan, students worksheet, and test meet practical standards. There is no difference based on the responses of students from three schools with different accreditations/quality (P-value $=$ 0.340 , with significance level $=0.05$ ). This response to mathematics teaching device demonstrates that it has meet effective standards and can be used in schools with different certification status. The mathematics teaching device with Quranic values meets the criteria for good teaching devices because it meets valid, practical, and effective criteria.
\end{abstract}

Keywords: Development; Teaching device; Mathematics; Science integrated; Quranic values

\footnotetext{
${ }^{1}$ Corresponding author: Widodo Winarso, widodoiain@gmail.com
} 


\section{Introduction}

Mathematics teaching device development is a series of processes or activities that are performed to create math teaching materials based on existing developmental theories. Huisman \& Tight (2015) describes development research based on two objectives: (1) development to acquire product prototypes, and (2) formulation of methodological proposals for prototype design and evaluation. Richey \& Klein, (2014) define development research as a systematic study of the design, development, and evaluation of programs, processes, and learning products that need to meet validity, practicality, and effectiveness criteria. Products are valid when they reflect the spirit of knowledge (state of the art knowledge) (Boudreau, Gefen, \& Straub, 2001). This criterion is interpreted as content validity. Therefore, the components of the product must be aligned with each other (structural validity) (Mueller, Lambert, \& Burlingame, 1998). Besides, if a product is considered usable, it is said to be practical. It is said to be effective if productivity results follow the goals set by the developer. Therefore, the development of a mathematics teaching device must meet all three aspects.

To develop teaching devices, teachers need the ability to plan and manage to learn effectively. Learning math can improve logical thinking skills, attitudes, and mathematical skills (Sitopu, Saragih, \& Hasratuddin, 2019). An effective teacher criterion is a teacher who can systematically prepare teaching devices (Moon, Mayes, \& Hutchinson, 2002). Learning preparations can be designed and organized as a teaching device. Teaching device is a key component of successful learning (Beard \& Wilson, 2014). Besides, teaching device can create learning that is interactive, exciting, fun, challenging, efficient, motivating students to actively participate (Gomez Martin, Gomez Martin, \& Gonzalez Calero, 2007), and has plenty of space for initiatives Provides (Myers \& AdamsBudde, 2016), creativity (Ubaidah \& Aminudin, 2019), independence according to talent, interest, student physical and psychological development (Posamentier, Jaye, \& Krulik, 2007; Permendikbud No 65, 2013). Other data showing the importance of developing mathematics teaching device are the results of a study by (Sitopu et al., 2019). The development of the mathematics teaching device can increase students' willingness and attitude toward higherorder thinking skills.

When implementing math learning in schools, some teachers have not yet developed their mathematical teaching device. Preliminary data from junior high schools in Cirebon, West Java, Indonesia indicate that teaching device needs to be developed. Eight teachers (66.67\%) take lesson plan online, and four teachers $(33.33 \%)$ create a lesson plan based on the results of questionnaire surveys on lessons and discussions with math teachers. Many teachers do not use learning models that can improve student attitudes and spirituality in their lesson plan. Most learning orientations focus on improving students' cognitive skills. The student worksheet used is a collection of exercises, usually purchased from a publisher or downloaded from the Internet. This situation indicates that teachers are not ready to develop a mathematics teaching device. 
Preparing a mathematics teaching device is part of the lesson plan (John, 2006). The lesson plan is designed in the form of a syllabus, lesson plan, student worksheet, and achievement test. There are several studies related to the development of the teaching device. For example, Kong, Looi, Chan, \& Huang (2017) have been studying the development of teaching device in the form of elearning in Singapore, Hong Kong, Taiwan, and Beijing, focusing on various development trends. The development of the teaching device can be done using Android software (Ahmar \& Rahman, 2017). teaching device can improve arithmetic and computational skills, graphical representation, construction of geometric and algebraic objects, problem-solving, and mathematical programming (Drigas \& Pappas, 2015).

Other studies related to the development of teaching devices using a specific learning model, such as the results of the study (Sitopu et al., 2019), have further developed teaching devices based on the Guided Discovery Model. Teaching device is used to improve students' understanding of concepts and mathematical critical thinking skills. Developing a teaching device with problem-based learning models based on cultural contexts can also improve students' mathematical communication and social skills (Aufa, Saragih, Practice, \& 2016, 2016). Developing problem-solving models using integrated patterns can improve problem-solving skills in math learning (Nurdyansyah, Masitoh, \& Bachri, 2018). Lee, Lim, \& Kim, (2017), on the other hand, prefer to develop learning design models using inverse proofs in problem-solving. Therefore, this research contributes to the planning of the teaching device, especially in the syllabus and lesson plan.

The development of the teaching device involves at least some innovations in learning assessment. For example, the study Park \& Jo, (2015) describes the development of a learning analytics dashboard to support student learning performance. (Artzt, 2015) have developed a guide for observation and selfassessment in reflex skill efforts. Additionally, (Winarso, 2018) has also developed a teaching device in the form of a full-scale assessment of students' mathematical attitudes, skills, and knowledge. These researchers have contributed to the development of mathematics teaching devices, such as syllabus, lesson plans, student worksheets, and achievement tests.

There seems to be no comprehensive development in the design of the teaching device based on the research of many researchers and teachers' problems. In particular, the development of a teaching device that provides an integrated overall model with the development of the four elements of the teaching device: syllabus, lesson plan, student worksheet, and achievement test. An alternative solution that can be offered in this study is the further development of integrated mathematics teaching device with Quranic values.

The integration of the Quranic values in mathematics learning is normatively aimed at achieving Quranic values (Islamic education) in mathematics learning activities that cover three aspects of student life (Kabir, 2013). First, the spiritual dimensions include Faith, religion, noble personality (Kabir, 2013; Nasr, 2013; 
Hixon \& Hixon, 2003). Second, the sociocultural dimension is a stable and independent personality, social, and national responsibility (Kabir, 2013; Laskier \& Lev, 2011) Third, the dimension of intelligence that leads to student progress: intellectual, creative, skilled, disciplined, work ethic, professional, innovative, productive (Mustaqimah, 2019; Kabir, 2013). When three-dimensional Quranic values are applied to mathematics teaching device, they can have a positive effect on students. It develops the student's potential to be a human who believes and serves God, noble, healthy, knowledgeable, talented, creative, independent, democratic and responsible citizen, Following the purpose of national education (RI Law Number 20 the Year 2003). Therefore, the conduct of learning activities must pay attention to the development of the student, that is, the development of aspects of the student's emotions, cognition, and psychomotor (Kasim \& Yusoff, 2014).

Conducting learning activities requires continued attention to student development, both in knowledge, personality, and spiritual development. Reality is just different than expected. Based on data from the Central Bureau of Statistics (BPS), Indonesia had 54,712 mischievous children or crimes in 2012 (51,400 in detention and 3,312 in prison). In 2012, there were 5,358 criminals throughout Indonesia (2,063 were detained, and 3,295 were given prisoner status). Similar issues were obtained from Indonesian Commission for the Protection of Children (KPAI) data for 33 states between January and June 2008 and reached four conclusions. The first $97 \%$ of junior and senior high school students watch pornography. Second, $93.7 \%$ of junior and senior high school students engage in genital stimulation (touching genitals), kissing activities, and oral sex. Third, $62.7 \%$ of junior high school students are no longer virgins. And lastly, 21.2\% of adolescents claimed abortion.

To overcome the problem of juvenile delinquency, the government, through the Indonesian Ministry of Education and Culture (Kemdikbud), aims to provide a curriculum that can meet the aims of national education. Develop of 2013 Curriculum (Kurtilas) as a solution to address these issues (Rumahlatu, Huliselan, \& Takaria, 2016; Retnawati, Hadi, \& Nugraha, 2016). Throughout Kurtilas, the government will provide a learning system that is oriented in four areas: spiritual, attitude, knowledge, and skills (Nur \& Madkur, 2014; Wahyudin \& Sukyadi, 2015). Indeed, the implementation of Kurtilas was not as smooth as expected, and many challenges and obstacles were facing educational institutions (Retnawati, 2016). It starts with the obstacles to developing a school curriculum, as well as implementing the curriculum.

Based on these criteria, it is important to provide examples of teaching devices that are appropriate for developing students' religious attitudes and spirituality. An integrated mathematics teaching device with Quranic values is an option according to the desired learning goal. However, the phenomena that occur indicate that learning mathematics in school needs to improve this ability through the development of teaching devices. Besides, it is still very rare for math learners to integrate Quranic values to find a specially designed teaching 
device. This situation demonstrates the importance of developing a teaching device integrated with the educational value contained in the Quran.

\section{Methodology}

Research Design

This research and development modify the Bennett, Borg, \& Gall, (1984) and Akker, Bannan, Kelly, Nieveen, \& Plomp, (2007) models that consist of design and implementation phases. The result of this research and development is an integrated mathematics teaching device with the Quranic Values. The teaching device includes syllabuses, lesson plans, student worksheets, and achievement tests.

\section{Research Procedure}

This $\mathrm{R} \& \mathrm{D}$ procedure refers to the stage in the 4-D development model developed by (Thiagarajan, SivasailamI, 1974). The four stages are definition, design, development, and dissemination.

During the definition phase, several analysis activities are performed as a reference for the initial product design. In other words, (1) basic problem analysis of math learning in schools and determination of alternative solutions to problem-solving, (2) student analysis on student characteristics and academic achievement, and (3) material by choosing developed competencies. Analysis, and (4) determination of selected basic competency indicators. The following is an initial product design that references the results of the analysis performed. The result of the initial design is called Draft 1. During the development phase (development), there are three phases of testing: professional testing, limited testing, and field testing. Perform specialized tests to determine the strength and from the results of the initial design of the mathematics teaching device (Draft 1). Devices that meet the valid criteria (draft 2) are then subjected to limited trials and field tests. Attempts were made to determine the practicality of the teaching device. The result of the revised limited trial is called Draft 3, and a field trial will be conducted to determine the effectiveness of the device under development. The final step is dissemination by submitting products to schools where research and scientific publications are conducted.

\section{Population and Sample}

The population of this study is a student of middle school (SMP/MTs) from the Cirebon District - Republic of Indonesia. Three middle schools (SMP/MTs) from the Cirebon district were selected as samples using a stratified random approach. The samples were selected based on the school's quality through the accreditation level. There are three levels of school accreditation, respectively, the best ones are A, B, and C. The samples consisted of experts, teachers, and students representing each school based on their accreditation level. Table 1 shows the distribution of samples in this study. 
Table 1. Distribution of Samples

\begin{tabular}{|c|c|c|c|c|}
\hline \multirow{2}{*}{ Subject } & \multicolumn{3}{|c|}{ Accreditation Level } & \multirow{2}{*}{ Total } \\
\hline & $\mathbf{A}$ & B & $\mathrm{C}$ & \\
\hline Student & 45 & 58 & 40 & 143 \\
\hline Teacher & 2 & 2 & 2 & 6 \\
\hline
\end{tabular}

\section{Data Collection Technique}

Data collection techniques for this study are using non-test techniques (Lazaraton \& Taylor, 2007). The non-test method is provided through the provision of the expert evaluation form, teacher evaluation forms, and student evaluation forms for the development of mathematics teaching device. The Instrument used in this study was a validation form and a questionnaire. Validation form is used to measure the validity of the device, which consists of the syllabus, lesson plan, student worksheet, and achievement tests. Teacher and student evaluation forms are used to measuring the practicality of teaching devices. Besides, we measured student responses to pioneers in developing mathematics teaching device at three schools with different levels of accreditation. This activity was done as a next step, a key consideration for product dissemination.

\section{Data Analysis}

Data analysis of this study was performed to determine the validity, practicality, and effectiveness of teaching device development (MacLeod, Yang, Zhu, \& Li, 2018). Expert judgment results were analyzed to determine the effectiveness aspects of the device. A teaching device is said to be valid if the results of the analysis performed on average fit into a valid category. Here, the validity analysis uses Aiken's validity index with the following formula (Aiken, 1980).

$$
V=\frac{\sum s}{n(c-1)}, s=r-I_{0}
$$

Information :

$\mathrm{V}=$ item validity index

$\mathrm{r}=$ respondent choice category score

$\mathrm{I}_{0}=$ lowest score in the scoring category

$\mathrm{c}=$ categories that respondents can choose from

$\mathrm{n}=$ the number of respondents

The purpose of the usability analysis is to determine whether the developed teaching device meets the practicality criteria. The usability of the device was analyzed based on data obtained from the teacher and student evaluations in a limited number of tests. A teaching device is said to be practical if the category of analysis for each device is minimally practical (Widoyoko, 2000). Usability analysis is performed by converting test data in five steps, as shown in Table 2. 
Table 2. Five-scale Actual Score Conversion

\begin{tabular}{cc}
\hline Interval Skor & Category \\
\hline$X i+1,8 \mathrm{SBi}<\mathrm{X}$ & Very good \\
$\mathrm{X} i+0,6 \mathrm{SBi}<\mathrm{X} \leq \mathrm{Xi}+1,8 \mathrm{SBi}$ & Good \\
$\mathrm{Xi}-0,6 \mathrm{SBi}<\mathrm{X} \leq \mathrm{Xi}+0,6 \mathrm{SBi}$ & Enough \\
$\mathrm{X} i-1,8 \mathrm{SBi}<\mathrm{X} \leq \mathrm{Xi}-0,6 \mathrm{SBi}$ & Less \\
$X \leq X i-1,8 \mathrm{SBi}$ & Very Less \\
\hline
\end{tabular}

Description:

$\mathrm{X}=$ Empirical Score

$\mathrm{Xi}=$ Average $=1 / 2($ maximum score + minimum score $)$

$\mathrm{SBi}=$ Standard Deviation $=1 / 6$ (maximum score - minimum score $)$

During the field trial phase, students' responses to the application of the results of the development of mathematics teaching device were analyzed. Different tests are needed to use samples from three schools with different criteria. This analysis is necessary to test the effectiveness of developing an integrated teaching device with Quranic values using the one-way analysis of variance Ftest (Moder, 2010). For advanced testing, use Post Hoc Multiple Comparisons (Kim, 2015).

\section{Result and Discussion}

\section{Define}

The definition phase focuses on analyzing needs and setting goals. Includes at this stage; identifying learning objectives, conducting learning analysis, analyzing student behavior and characteristics, and creating specific learning. This phase is implemented through five information-gathering strategies related to products developed to overcome the problems found in math learning at SMP/MTs in the Cirebon district (Thiagarajan, SivasailamI, 1974).

Table 3. Analysis of needs and formulation objectives

\begin{tabular}{ll}
\hline \multicolumn{1}{c}{ Strategy } & \multicolumn{1}{c}{ Description of findings } \\
\hline $\begin{array}{l}\text { Front-end } \\
\text { analysis }\end{array}$ & $\begin{array}{l}\text { Based on interviews with middle school mathematics teachers } \\
\text { in the Cirebon district, researchers were informed that the } \\
\text { curriculum used was Kurtilas. Exercises included in the } \\
\text { textbook. There are three groups with different characteristics } \\
\text { in learning absorption. } \\
\text { That is the abilities of students in accredited grades A, B, and C } \\
\text { schools. The abilities of students at accredited C-level schools } \\
\text { are uneven. Schools with A-certified titles have an even } \\
\text { distribution of student abilities, and average performance is } \\
\text { better than the average for B and C-certified students. This } \\
\text { condition is almost the same as a student in a school that warns } \\
\text { of C certification, but below the average for students in a } \\
\text { predicate school with certification A. }\end{array}$ \\
\hline $\begin{array}{l}\text { Learner } \\
\text { analysis }\end{array}$ & $\begin{array}{l}\text { Students are still ashamed to ask questions and hate if they } \\
\text { come to the top of the class and are asked to explain the work } \\
\text { discussed. }\end{array}$ \\
\hline
\end{tabular}


- This condition can be seen in their activities while learning in class. Some students are busy in the class and do not pay attention when teachers explain in front of the class. Some students are still unwilling to study math.

- This condition is evidenced by the fact that there are still students who forget to do their homework and bring in other tools such as books, stationery, and rulers.

- Some students have low, but not enough, math scores.

- When starting to study, especially when starting to study mathematics, students rarely still pray or read Bismillah.

\begin{tabular}{|c|c|}
\hline Task analysis & $\begin{array}{l}\text { - Students are more active in asking questions and } \\
\text { communicating their understanding with other students. } \\
\text { - Students are willing to complete a given task and pay attention } \\
\text { to all the explanations provided. } \\
\text { - Students are eager to learn math. } \\
\text { - Students get high or satisfactory grades. } \\
\text { - Students can understand the teaching materials well. } \\
\text { - Students are accustomed to praying before they start learning. }\end{array}$ \\
\hline $\begin{array}{l}\text { Concept } \\
\text { analysis }\end{array}$ & $\begin{array}{l}\text { - Schools need a curriculum and a variety of activities that can } \\
\text { fulfill their vision and mission. } \\
\text { - Teachers need a mathematics teaching device that can improve } \\
\text { not only math learning outcomes but also shape students who } \\
\text { behave in an Islamic way. } \\
\text { - Students need math learning activities that can develop } \\
\text { understanding and spirituality. }\end{array}$ \\
\hline $\begin{array}{l}\text { Specifying } \\
\text { instructional } \\
\text { objectives }\end{array}$ & $\begin{array}{l}\text { By developing high-quality mathematics teaching device in terms of } \\
\text { validity, practicality, and effectiveness based on scientific and Quran } \\
\text { values, students excel in mathematical attitude and religious } \\
\text { spirituality. }\end{array}$ \\
\hline
\end{tabular}

\section{Design}

Indonesian government policy applies the 2013 curriculum (Kurtilas), which must integrate information technology and scientific approaches to all subjects, including mathematics (Purnamaningwulan, 2019; Mtebe \& Kissaka, 2015). Managing classroom learning requires the development and use of teaching devices (Karakas, Manisaligil, \& Sarigollu, 2015). Teaching device is devices used in the teaching and learning process (Owen \& Sweller, 1989). The teaching device needed to manage teaching and learning will take the form of syllabuses, lesson plans, student worksheets, and achievement tests (Washburn, 1992).

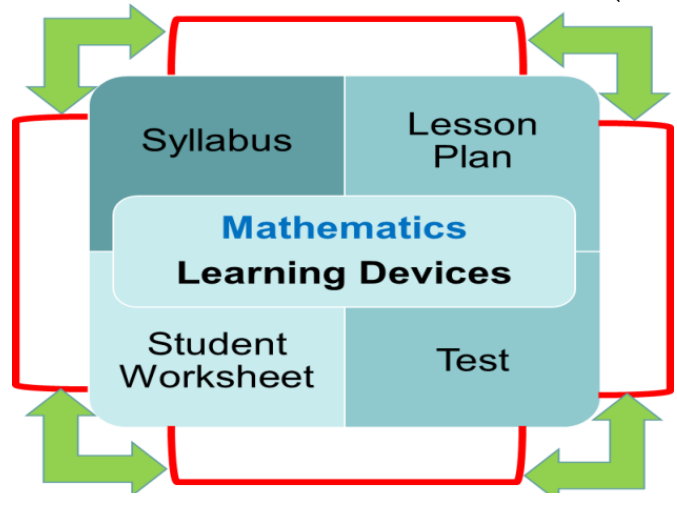

Figure 1. Mathematics Teaching Devices 
Based on Figure 1, four teaching devices have been developed with a scientific learning approach. The scientific approach (Colburn, 2000; Hodson \& Hodson, 1998) as one of the approaches that must be used for the application of Kurtilas, which is a manifestation of the constructivist approach. In this approach, students are given the most part to play a role in ongoing learning (Garrett, The, Interaction, \& Case, 2015; Catalano \& Catalano, 1999). That part can be seen from the following syntax (learning procedure). Observations, questions, trials, associations, and communication (Sumarmo, Kusnadi, \& Maya, 2018).

On that journey, Kurtilas experienced many developments and enhancements. One is to implement strengthening character education (PPK) in Indonesia's national education system (Aisyah, Samawi, \& Untariana, 2018). Key values expected through the PPK include religion, nationalism, independence, cooperation, and honesty (Sulistyarini, Utami, \& Hasmika, 2019). In addition to enhancing character education, facing the challenges of the 21st century requires students to strengthen their skills. Skills facing the challenges of the 21st century are known as $4 \mathrm{C}$, including communication, collaboration, critical thinking, and creativity (Jefferson \& Anderson, 2017). Besides, for students to have these skills, they need to ask HOT questions and provide support to enhance student literacy (Sulastri, Rintayati, \& Sarwono, 2019). These are both prerequisites or support for the development of future four skill (4C) students.

Curriculum development in Indonesia, which prioritizes the enhancement of knowledge, skills, and personality education in learning, still suggests the current lack of particular performance (Mohamad, Kulap, \& Hamdiyah, 2018). The flaws in the matter are juvenile delinquency and moral issues rampant among students. Deteriorating morals has led to a controversy in the national education system (Albantani \& Madkur, 2016).

Given this situation, we need a catalyst that can accelerate the process of absorbing information about Kurtilas and various enhancements. Catalyst means increasing the value of the Quran in learning activities (Hudhana, 2015). Of course, the Quran is very close to the lives of Indonesian people, especially Muslim people. Many people read, memorize, and practice this holy scripture book every day. Many formal and informal educational institutions, organized by government or non-governmental organizations, study and learn this holy scripture. Many Islamic boarding schools (Pesantren) and Islamic recitations (Pengajian) scattered throughout the country are ready to discuss and study the Quran, raise awareness about the values contained in the Quran, and provide the public with material (Herdiansyah, Jokopitoyo, \& Munir, 2016).

It is also known that the Quran's principles and values are consistent with Indonesian education. Even the founder of this country used the Quran as a reference in shaping the ideology of the state, as stated in Pancasila and the 1945 Constitution. In the Quran (Cahyaningtyas, 2018). That is, the value of the Quran is packaged and widely accepted under other names so as not to compromise its diversity. 
Therefore, there is a need to enhance Kurtilas through the innovation of mathematics teaching device integrated with the value of the Quran. The simplicity of the goal can help us to absorb information about Kurtilas more quickly. Indonesians who are mentally close to the Quran are certainly familiar with the values contained in the Quran and apply it more easily in all their lives, including education. With the Quran value as a catalyst, most educators are expected to have a better understanding of Kurtilas. You can compare the values included in the PPK and 4C skills with the values included in the Quran. Besides, for a deeper understanding of Kurtilas, learning activities and assessment of Kurtilas are easier to carry out. Figure 2 shows the hierarchical structure of the developers.

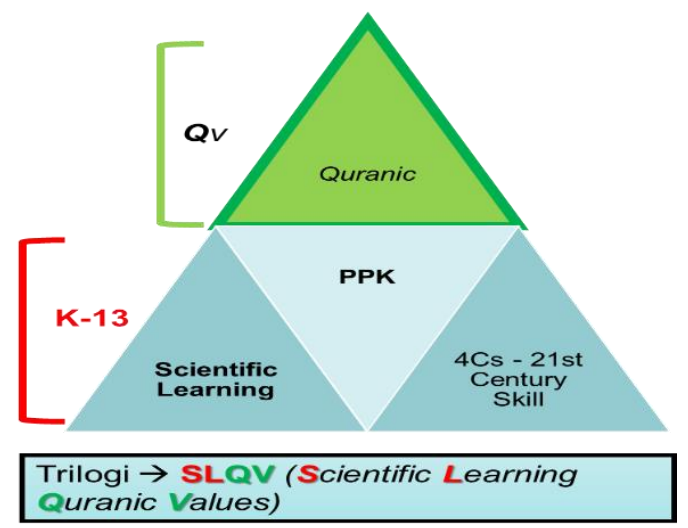

Figure 2. SL-QVModel

Based on Figure 2, the Design phase, which takes place, looks for Quranic Values related to learning activities. Next, extract the educational value contained in it. Search results related to the Quranic values are mapped to learning goals, learning methods, mathematics subjects, learning activities, dan learning evaluation in Table 4.

Table 4. Al-Quran verses related to learning

\begin{tabular}{|c|c|c|}
\hline $\begin{array}{l}\text { Curriculum } \\
\text { Structure }\end{array}$ & $\begin{array}{l}\text { Letters dan Verses } \\
\text { From Al-Qur'an }\end{array}$ & Quranic Content \\
\hline \multirow[t]{4}{*}{$\begin{array}{l}\text { Learning } \\
\text { Goals }\end{array}$} & $\begin{array}{l}\text { QS. Al-Hujurat, } \\
49: 13\end{array}$ & $\begin{array}{l}\text { The purpose of learning is to be a person } \\
\text { dedicated to Allah }\end{array}$ \\
\hline & $\begin{array}{l}\text { QS. Ali Imran, 3:190- } \\
191\end{array}$ & $\begin{array}{l}\text { The purpose of learning is to become a person } \\
\text { with faith and knowledge }\end{array}$ \\
\hline & QS. Al-Ahzab, 33:21 & $\begin{array}{l}\text { The purpose of learning is to become a noble } \\
\text { person }\end{array}$ \\
\hline & QS. At-Taubah, 9:122 & $\begin{array}{l}\text { The purpose of learning is to warn his people } \\
\text { and help them protect themselves }\end{array}$ \\
\hline \multirow[t]{5}{*}{$\begin{array}{l}\text { Learning } \\
\text { Methods }\end{array}$} & QS. An-Nahl, 16:125 & $\begin{array}{l}\text { Wisdom method, good advice/coaching } \\
\text { method, and Jidal method (discussion) }\end{array}$ \\
\hline & QS. Al-Maidah, 5:31 & Imitation Method \\
\hline & QS. Al-Ahzal & \\
\hline & QS. Yusuf, 12:2-3 & Story method \\
\hline & $\begin{array}{l}\text { QS. Al-Ankabut, } \\
29: 20\end{array}$ & $\begin{array}{l}\text { Method of practical experience (trial and error), } \\
\text { method of thinking }\end{array}$ \\
\hline
\end{tabular}




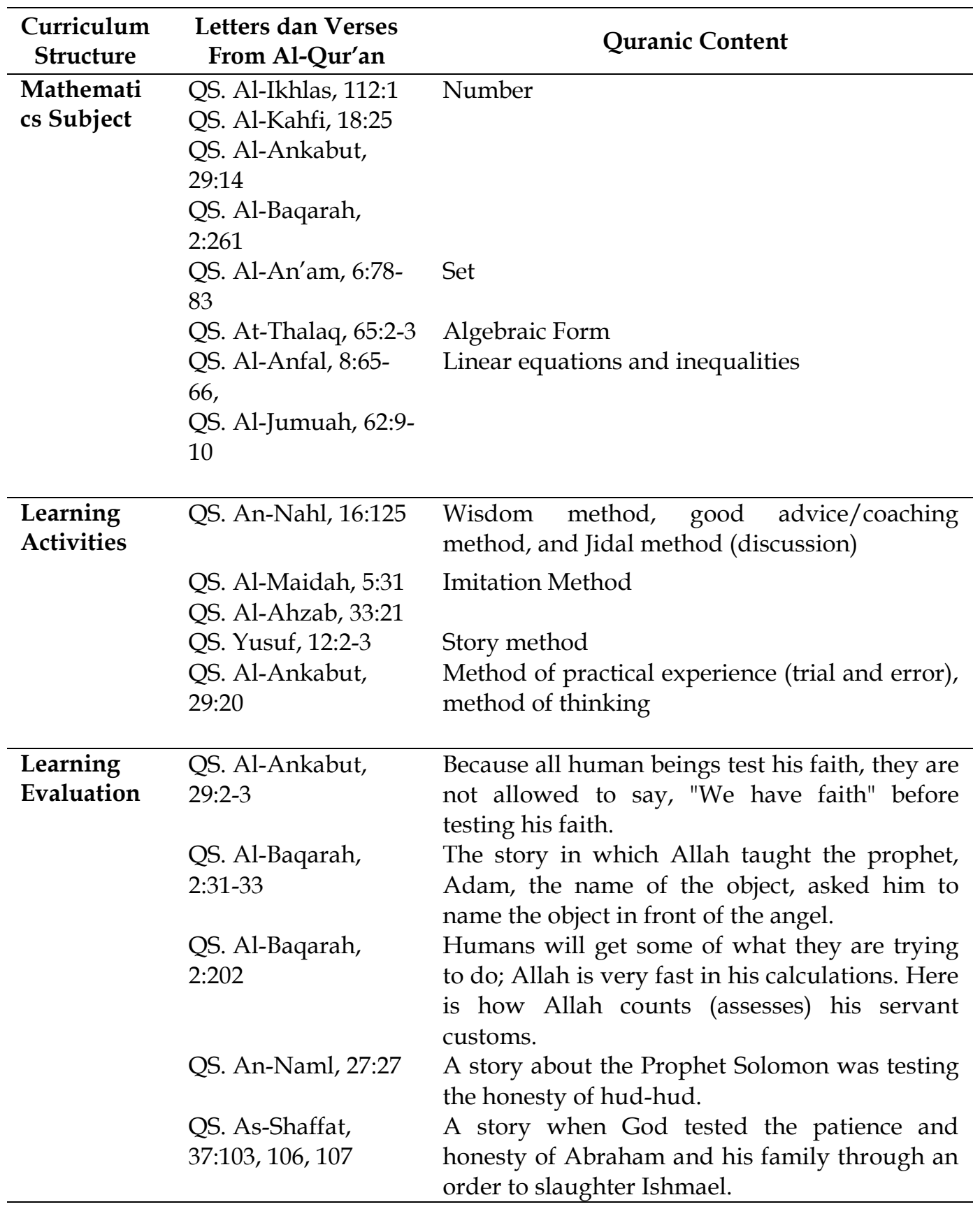

\section{Develop}

Data from professional exams

During the development phase, the step of developing an integrated teaching device for the Quranic value is first to perform an expert evaluation (effectiveness test). The purpose is to check the quality of the product from a content perspective. Two experts perform the effectiveness of the teaching devices by assessing the syllabus, lesson plan, student worksheet, and achievement test. The data relevant to the validity test results in Table 5 are as follows. 
Table 5. Syllabus validation results

\begin{tabular}{lcccc}
\hline \multirow{2}{*}{\multicolumn{1}{c}{ Rated aspect }} & \multicolumn{2}{c}{ Score } & Aiken & \multirow{2}{*}{ Criteria } \\
\cline { 2 - 3 } Index & $\mathbf{1}$ & $\mathbf{2}$ & \\
\hline Syllabus Format & 13 & 14 & 0,75 & Valid \\
Syllabus Component & 22 & 24 & 0,75 & Valid \\
Subject Identity & 25 & 26 & 0,67 & Valid \\
Basic Competencies & 13 & 12 & 0,68 & Valid \\
Indicator & 25 & 27 & 0,70 & Valid \\
Learning Subject & 13 & 15 & 0,78 & Valid \\
Learning Activities & 16 & 20 & 0,74 & Valid \\
Assessment of Learning & 16 & 20 & 0,74 & Valid \\
Outcomes & & & & \\
Selection of learning resources & 23 & 22 & 0,73 & Valid \\
Time Allocation & 22 & 24 & 0,75 & Valid \\
Power of language & 22 & 24 & 0,75 & Valid \\
\hline \multicolumn{1}{c}{ Total } & $\mathbf{2 1 0}$ & $\mathbf{2 2 8}$ & $\mathbf{0 , 7 3}$ & Valid \\
\hline
\end{tabular}

Based on Table 5, verifier evaluation results relating to both the first and second experts are included in both categories, as the syllabus is declared valid. Besides, syllabus evaluation is performed by teachers, resulting in high-quality results, and evaluation of student responses are categorized into appropriate categories. The syllabus can now be declared practical - the effective results of the learning plan in Table 6.

Table 6. Validation Results of Learning Implementation Plan

\begin{tabular}{lcccc}
\hline \multirow{2}{*}{\multicolumn{1}{c}{ Rated aspect }} & \multicolumn{2}{c}{ Score } & Aiken & \multirow{2}{*}{ Index } \\
\cline { 2 - 3 } & $\mathbf{1}$ & $\mathbf{2}$ & Criteria \\
\hline Learning Plan Format & 16 & 20 & 0,74 & Valid \\
Subject Identity & 16 & 20 & 0,74 & Valid \\
Formulation of learning & 23 & 22 & 0,73 & Valid \\
Objectives & & & & \\
Conformity of Learning Subject & 25 & 26 & 0,67 & Valid \\
Learning Model & 22 & 24 & 0,75 & Valid \\
Learning Activity & 13 & 14 & 0,75 & Valid \\
Selection of learning resources & 25 & 27 & 0,70 & Valid \\
Assessment of Learning & 25 & 26 & 0,67 & Valid \\
Outcomes & & & & \\
Power of language & 23 & 22 & 0,73 & Valid \\
\hline \multicolumn{1}{c}{ Total } & $\mathbf{1 8 8}$ & $\mathbf{2 0 1}$ & $\mathbf{0 , 7 2}$ & Valid \\
\hline
\end{tabular}

Based on Table 6, the results of the verifier's evaluation of the lesson plan show that each component of the lesson plan has a valid category and that the average result of the total analysis has a valid category. Besides, teachers' assessments of lesson plans are in a good category, and student responses are also in a good category so that lesson plans can be declared practically. The results of the evaluation and analysis of the Student Worksheet validation assessment data show that all aspects have valid standards. The results of the LKS evaluation and analysis are reviewed from all aspects, as shown in Table 7. 
Table 7. Validation Result of student worksheets

\begin{tabular}{|c|c|c|c|c|}
\hline \multirow{2}{*}{ Rated aspect } & \multicolumn{2}{|c|}{ Score } & \multirow{2}{*}{$\begin{array}{c}\text { Aiken } \\
\text { Index }\end{array}$} & \multirow{2}{*}{ Criteria } \\
\hline & 1 & 2 & & \\
\hline Suitability of contents and subject & 13 & 15 & 0,83 & Valid \\
\hline Layout Settings & 22 & 24 & 0,82 & Valid \\
\hline Language Component & 25 & 26 & 0,73 & Valid \\
\hline Presentation Component & 13 & 12 & 0,68 & Valid \\
\hline Benefits/Uses & 25 & 27 & 0,68 & Valid \\
\hline $\begin{array}{l}\text { Conformity with the integration of } \\
\text { quranic values }\end{array}$ & 13 & 15 & 0,83 & Valid \\
\hline Total & 93 & 103 & 0,70 & Valid \\
\hline
\end{tabular}

The results of the verifier evaluation of the student achievement test meet valid criteria. The assessment data is based on two aspects: metrics and the suitability of the question editor, as shown in Table 8.

Table 8. Validation Result of Test

\begin{tabular}{|c|c|c|c|c|}
\hline \multirow{2}{*}{ Rated Aspect } & \multirow{2}{*}{$\begin{array}{l}\text { Max } \\
\text { Score }\end{array}$} & \multicolumn{2}{|c|}{ Score } & \multirow{2}{*}{ Criteria } \\
\hline & & 1 & 2 & \\
\hline Indicator Suitability & 45 & 45 & 45 & Valid \\
\hline Content of question & 45 & 45 & 45 & Valid \\
\hline Total & 90 & 90 & 90 & Valid \\
\hline
\end{tabular}

On the other hand, based on the evaluation of the content of the learning device, Table 9 shows both the syllabus, the lesson plan, the worksheet, and the professional pre-test test for the student.

Table 9. Content assessment based on expert opinion

\begin{tabular}{|c|c|c|c|}
\hline $\begin{array}{c}\text { Device } \\
\text { Type }\end{array}$ & $\begin{array}{c}\text { Revision } \\
\text { Source }\end{array}$ & Before Revision & After Revision \\
\hline \multirow[t]{4}{*}{ Syllabus } & $\begin{array}{l}\text { Expert } \\
\text { judgment }\end{array}$ & $\begin{array}{l}\text { The indicator used does } \\
\text { not use operational verbs }\end{array}$ & $\begin{array}{l}\text { Indicators use operational } \\
\text { verbs }\end{array}$ \\
\hline & & No information on & Add/insert Quranic values \\
\hline & & $\begin{array}{l}\text { Quranic values in each } \\
\text { learning activity }\end{array}$ & at every stage of learning \\
\hline & & $\begin{array}{l}\text { There are no Quranic } \\
\text { values in the learning } \\
\text { source }\end{array}$ & $\begin{array}{l}\text { Added Quranic values to the } \\
\text { Learning Resources column }\end{array}$ \\
\hline \multirow[t]{3}{*}{$\begin{array}{l}\text { Lesson } \\
\text { Plan }\end{array}$} & $\begin{array}{l}\text { Expert } \\
\text { judgment }\end{array}$ & $\begin{array}{l}\text { The learning procedure is } \\
\text { unknown }\end{array}$ & $\begin{array}{l}\text { Stages that make learning } \\
\text { steps more clear }\end{array}$ \\
\hline & & $\begin{array}{l}\text { The core activities of the } \\
\text { learning step do not use } \\
\text { the latest formats ( } 2017 \\
\text { revised curriculum), } \\
\text { including 4C (creativity, } \\
\text { collaboration, critical } \\
\text { thinking, communication). }\end{array}$ & $\begin{array}{l}\text { Use the latest Kurtilas } \\
\text { formats, including } 4 \mathrm{C} \\
\text { (creativity, collaboration, } \\
\text { critical thinking, and } \\
\text { communication) in core } \\
\text { activities. }\end{array}$ \\
\hline & & $\begin{array}{l}\text { The learning procedure } \\
\text { involving the Quranic } \\
\text { values is not yet } \\
\text { clear/invisible. }\end{array}$ & $\begin{array}{l}\text { Learning steps with Quranic } \\
\text { values are displayed because } \\
\text { they are color-coded }\end{array}$ \\
\hline
\end{tabular}




\begin{tabular}{|c|c|c|c|}
\hline \multirow[t]{3}{*}{$\begin{array}{l}\text { Student } \\
\text { Worksheet }\end{array}$} & $\begin{array}{l}\text { Expert } \\
\text { judgment }\end{array}$ & $\begin{array}{l}\text { Student worksheet rating } \\
\text { not yet clear }\end{array}$ & $\begin{array}{l}\text { Added evaluation using the } \\
\text { student worksheet point } \\
\text { system. All students earn } \\
\text { points for performing certain } \\
\text { activities listed on the } \\
\text { worksheet. Students will be } \\
\text { considered to meet the } \\
\text { minimum criteria if they } \\
\text { have earned a } \\
\text { predetermined number of } \\
\text { points. }\end{array}$ \\
\hline & & $\begin{array}{l}\text { Student worksheet does } \\
\text { not display the ability of } \\
\text { students to achieve }\end{array}$ & $\begin{array}{l}\text { Added ability maps include } \\
\text { the student's abilities } \\
\text { achievement. Interesting } \\
\text { pictures are also displayed } \\
\text { on the competency map. }\end{array}$ \\
\hline & & $\begin{array}{l}\text { The steps/sections of the } \\
\text { worksheet are not well } \\
\text { organized to confuse } \\
\text { students and teachers. }\end{array}$ & $\begin{array}{l}\text { Added ability maps include } \\
\text { the abilities that students } \\
\text { achieve. Interesting photos } \\
\text { are also displayed on the } \\
\text { competency map. }\end{array}$ \\
\hline Test & $\begin{array}{l}\text { Expert } \\
\text { judgment }\end{array}$ & $\begin{array}{l}\text { The rubric for multiple- } \\
\text { choice questions does not } \\
\text { yet show instructions (final } \\
\text { answer only) }\end{array}$ & $\begin{array}{l}\text { Added numbers and color } \\
\text { codes to distinguish each } \\
\text { activity on the worksheet. } \\
\text { Make Student worksheets } \\
\text { easier for teachers and } \\
\text { students to use. Added steps } \\
\text { to address multiple choice } \\
\text { rubric questions }\end{array}$ \\
\hline
\end{tabular}

\section{Limited test data}

Evaluation of learning tools performed on six teachers. Teachers' evaluations of the developed syllabus, lesson plans, and learning outcome tests meet practical standards. The results of the teacher evaluation of the developed worksheets meet very practical criteria. Table 10 shows the results of the evaluation and analysis of the lesson plan data by six teachers.

Table 10. Teacher Assessment on Teaching Devices

\begin{tabular}{lcccc}
\hline \multirow{2}{*}{ Evaluator } & \multicolumn{4}{c}{ The total score for each aspect } \\
\cline { 2 - 5 } & Syllabus & Lesson Plan & $\begin{array}{c}\text { Student } \\
\text { Worksheet }\end{array}$ & $\begin{array}{c}\text { Achievement } \\
\text { Test }\end{array}$ \\
\hline Teacher 1 & 38 & 32 & 37 & 30 \\
Teacher 2 & 26 & 30 & 41 & 33 \\
Teacher 3 & 30 & 30 & 32 & 30 \\
Teacher 4 & 30 & 30 & 30 & 28 \\
Teacher 5 & 34 & 32 & 40 & 30 \\
Teacher 6 & 34 & 32 & 40 & 30 \\
\hline Average & $\mathbf{3 2}$ & $\mathbf{3 1}$ & $\mathbf{3 6 , 6 7}$ & $\mathbf{3 0 , 1 7}$ \\
\hline Criteria & \multirow{2}{*}{ Practical } & Practical & Very & Practical \\
\hline
\end{tabular}


Besides, student worksheet student evaluation results were obtained, and the developed achievement test meets very practical criteria. Table 11 shows the results of the evaluation and analysis of the student worksheet evaluation data and the results of the achievement test.

Table 11. Student Assessment on Teaching Devices

\begin{tabular}{cccc}
\hline Evaluator & Max Score & Average Score & Category \\
\hline Student & 45 & 39,25 & Practical \\
$\begin{array}{c}\text { Worksheet } \\
\text { Acivement } \\
\text { Test }\end{array}$ & 35 & 23,5 & Practical \\
\hline
\end{tabular}

Table 12 shows syllabuses, lesson plans, student worksheets, and both teacher and student tests for assessing the content of the teaching device.

Table 12. Content assessment is based on the teacher's opinion and student response

\begin{tabular}{|c|c|c|c|}
\hline Device Type & $\begin{array}{l}\text { Revision } \\
\text { Source }\end{array}$ & Before Revision & After Revision \\
\hline Syllabus & $\begin{array}{l}\text { Teacher } \\
\text { Evaluation }\end{array}$ & $\begin{array}{l}\text { The syllabus is good and } \\
\text { does not need to be revised. }\end{array}$ & - \\
\hline Lesson Plan & $\begin{array}{l}\text { Teacher } \\
\text { Evaluation }\end{array}$ & $\begin{array}{l}\text { The index of the Quranic } \\
\text { values is missing, or the } \\
\text { index used is incomplete } \\
\text { and displays all poems } \\
\text { relevant to learning. }\end{array}$ & $\begin{array}{l}\text { Added an index of } \mathrm{Al} \\
\text { Quranic values related to } \\
\text { learning activities, } \\
\text { although the Index limited } \\
\text { to certain mathematics } \\
\text { subject materials. }\end{array}$ \\
\hline $\begin{array}{l}\text { Student } \\
\text { Worksheet }\end{array}$ & $\begin{array}{l}\text { Teacher } \\
\text { and } \\
\text { Student } \\
\text { Evaluation }\end{array}$ & $\begin{array}{l}\text { A student worksheet is } \\
\text { good and does not need to } \\
\text { be modified. }\end{array}$ & - \\
\hline $\begin{array}{l}\text { Achievement } \\
\text { Test }\end{array}$ & $\begin{array}{l}\text { Teacher } \\
\text { and } \\
\text { Student } \\
\text { Evaluation }\end{array}$ & $\begin{array}{l}\text { The tests are good and do } \\
\text { not need to be modified. }\end{array}$ & - \\
\hline
\end{tabular}

Field test result data

Table 13. Test homogeneity of variances

\begin{tabular}{ccccc} 
Student Response & & & \\
\hline Levene Statistic & df1 & \multicolumn{1}{c}{ df2 } & Sig. \\
\hline 1.694 & 2 & 141 & .187
\end{tabular}

Based on Table 13, the Anova test has Quranic values because the variance uniformity test shows that the results of the field trial show that the three groups have the same variant $(P$-value $=0.187>0.05)$ Useful for testing student response relationships to teaching device applications. 
Table 14. Anova differences in student responses

Student Response

\begin{tabular}{lcrrrr}
\hline & $\begin{array}{l}\text { Sum of } \\
\text { Squares }\end{array}$ & df & Mean Square & F & Sig. \\
\hline Between Groups & 273.515 & 2 & 136.758 & 1.088 & .340 \\
\hline Within Groups & 17730.235 & 141 & 125.746 & & \\
\hline Total & 18003.750 & 143 & & & \\
\hline
\end{tabular}

Also, the results of the Anova test confirm differences in student response to the application of teaching device tools using the Quranic values of the three accredited groups. From Sig Table 14. Obtained P-value $(\mathrm{P}$-value) $=0.340$. Therefore, a significance level $=0.05$ Ho is accepted, which translates into an insignificant difference in the average score of student responses based on the three accredited groups. Mathematics Teaching devices with Quranic values can be developed at various types of schools, both accredited and non-accredited. Besides, the test results show Ho (no difference), so no further tests (Post Hoc Test) will be performed in the next analysis phase.

\section{Product revision}

The revision of the integrated mathematics teaching device, especially Quranic values. First, complete the syllabus, lesson plan, student worksheet, and achievement test according to the advice of the two validation expert. Second, add an index of Quranic values and divide them into five types of Quranic values related to learning goals, learning methods, mathematics subject material, learning activities, and learning evaluations. Third, improve student worksheets and achievement tests according to teacher and student suggestions.

\section{Disseminate}

Mathematics teaching devices integrated with Quranic values can improve students' religious spirituality and mathematical attitudes. Religious spirituality is shown in how a student is respectful, has faith in Allah, and performs the worship he requires. This is in line with the research results of Hammawa \& Hashim (2016) that the values contained in the Quran affect a person's spirituality. Other than that Impact of the Quran in the treatment of the psychological disorder and spiritual illness (Saged et al., 2018), the Quran also have an impact on student learning attitudes (Fathi, Ebrahimzadeh, Charati, Rostamnezhad, \& Shelimaki, 2017). The religious spiritualities of the students discussed in this study are similar to the religious attitudes described in the strengthening character education (PPK) in Kurtilas (Cahyaningtyas, 2018). Besides, the mathematical attitude of the problem is the mathematical attitude that the student gained when learning math. One mathematical attitude is that students tend to be more thorough and solve problems. Mathematical attitudes are also closely related to strengthening skills (4C) to address 21st-century challenges (Falsetti \& Rodríguez, 2005).

A mathematics teaching device integrating the Quranic values developed regarding the background findings and the analysis results during the definition 
phase. Media selection, format selection, and initial product design are performed based on the results of the subsequent analysis. The initial product design is then performed during the testing phase: expert, limited, and hands-on testing. At each stage of the test, modifications or improvements are made to the product under development to qualify. The device was evaluated for its feasibility based on three aspects: (a) effectiveness, (b) practicality, and (c) effectiveness. Form learning tools: lesson plan, student worksheet, and developed achievement test meet valid criteria based on content validity by two experts. This condition indicates that the components of the teaching device that have been developed comply with the indicators set for the means of teaching device effectiveness. The teaching devices developed also have a strong theoretical relationship, and there is internal consistency between the components of the device under development (Inglis \& Alcock, 2012).

The usability of a teaching device is based on teacher ratings and student ratings (readability). Based on data analysis, it shows that the teaching device developed to fit into practical categories. This condition is shown from the average score of student ratings in the practical category, but the average score of teacher ratings for learning devices is a very practical category.

Teaching device products, lesson plan, and student worksheets meet effective standards. This condition means that there is consistency between the configured training set and the implemented training set, and the configured training set and the goals to be achieved. The efficient criteria are met based on an analysis of student response data from three different types of schools (Accreditation A, B, and C) and show no significant differences. This condition shows that schools with different quality schools can accept and use the teaching device.

Based on a review of the above three aspects, the mathematics teaching device integrates Quranic values to develop students' spirituality and mathematical attitude and meets valid, practical, and effective standards Can be concluded. This condition shows that the developed device is suitable for learning mathematics. In line with the opinion of (Nieveen, 1999) that state quality aspects of the key considerations of teaching device must pay attention to three aspects of effectiveness, practicality, and effectiveness.

\section{Research restrictions}

As this study is still in its early stages of development, the materials used in the teaching device are still limited to set materials. Besides, the SL-QV model used as a concept in this study needs further refinement to make the output clearer. This study is limited to SMP/MTs (middle schools) so that it can be developed at other educational levels.

\section{Conclusion}

The research conducted, namely, the development of a mathematics teaching device integrated with the Quranic values was stated to meet the criteria for validity, practicality, and effectiveness. Therefore, specifically developed 
teaching device is suitable for use in SMP/MTs (middle school) level learning activities. In general, mathematics teaching device integrated into the values of the Quran can be used as a reference for further development of teaching materials and other levels of education. From two experts as verifiers, the syllabus rating scores 210 and 228 met the valid criteria. The lesson plan evaluation scores of 188 and 201 meet the valid criteria. Student worksheet assessment scores of 93 and 103 meet valid criteria. Finally, an achievement test score of 90 and 90 meets the valid criteria. Besides, from 6 teachers as teaching device evaluators, 32 syllabus scores, 31 lesson plan scores, 36.67 student worksheet scores, and 30.17 achievement test scores. Syllabus scores, lesson plan, and achievement tests meet practical standards, and student worksheet scores meet very practical standards. Finally, a P-value (P-value) $=0.340$ was obtained based on the results of the Anova one-way F-test. Therefore, accept Ho at the actual level $=0.05$. Therefore, the conclusion obtained is that there is no significant difference in the average score of student responses based on the three accredited groups. Based on these results, the teaching device can be applied to schools that meet effective standards and have varying levels of accreditation (quality).

\section{Acknowledgments}

Thanks to the Indonesian Ministry of Religious Affairs. The study was funded through DIPA IAIN Syeikh Nurjati Cirebon in 2019.

\section{References}

Ahmar, A. S., \& Rahman, A. (2017). Development of teaching material using an Android. Global Journal of Engineering Education, 19(1), 72-76. https://doi.org/10.26858/gjeev19i1y2017p7376

Aiken, L. R. (1980). Content Validity and Reliability of Single Items or Questionnaires. Educational and Psychological Measurement, 40(4), 955-959. https:/ / doi.org/10.1177/001316448004000419

Aisyah, E. N., Samawi, A., \& Untariana, A. F. (2018). Efforts to Improve the Ability of The Teachers in Development Program for Strengthening Character Education (PPK) in Early Childhood Education (ECE) through Workshop Activities. Advances in Social Science, Education and Humanities Research. Proceedings of the 1st International Conference on Early Childhood and Primary Education (ECPE 2018), Malang, Indonesia, 38-41. https:/ / doi.org/10.2991/ecpe-18.2018.9

Akker, J. van den, Bannan, B., Kelly, A. E., Nieveen, N., \& Plomp, T. (2007). Curriculum design research: An introduction to educational design research. East, 37, 129. Retrieved from www.slo.nl/organisatie/international/publications

Albantani, A. M., \& Madkur, A. (2016). Integrating charatcer education values in language teaching: why and how? The 4th ELITE International Conference, 400-414. Syarif Hidayatullah State Islamic University, Jakarta: Department of English Education.

Artzt. (2015). Becoming a Reflective Mathematics Teacher. In Becoming a Reflective Mathematics Teacher. London, UK: Routledge.

Aufa, M., Saragih, S., \& Minarni, A. (2016). Development of Learning Devices through Problem Based Learning Model Based on the Context of Aceh Cultural to Improve 
Mathematical Communication Skills and. Journal of Education and Practice, 7(24), 232-248. Retrieved from https://eric.ed.gov/?id=EJ1112888

Beard, C., \& Wilson, J. P. (2014). Experiential Learning: a Handbook for Education, Training and Coaching. In Human Resource Management International Digest. London, UK: Kogan Page Publishers.

Bennett, N., Borg, W. R., \& Gall, M. D. (1984). Educational Research: An Introduction. British Journal of Educational Studies, 32(3), 274-284. https://doi.org/10.2307/3121583

Boudreau, M. C., Gefen, D., \& Straub, D. W. (2001). Validation in Information Systems Research: A State-of-the-Art Assessment. MIS Quarterly, 25(1), 1-16. https://doi.org/10.2307/3250956

Cahyaningtyas, A. P. (2018). The Concept of Character Values in Curicullum 2013: An Islamic Perspective. Internationalization of Islamic Higher Education Institutions Toward Global Competitiveness, 394-399. Retrieved from http://jurnal.unissula.ac.id/index.php/bksptis/article/view/3599

Catalano, G. D., \& Catalano, K. (1999). Transformation: From Teacher-Centered to Student-Centered Engineering Education. Journal of Engineering Education, 88(1), 59-64. https://doi.org/10.1002/j.2168-9830.1999.tb00412.x

Colburn, A. (2000). Constructivism: Science Education's "Grand Unifying Theory." The Clearing House: A Journal of Educational Strategies, Issues and Ideas, 74(1), 9-12. https://doi.org/10.1080/00098655.2000.11478630

Drigas, A., \& Pappas, M. (2015). A Review of Mobile Learning Applications for Mathematics. International Journal of Interactive Mobile Technologies (IJIM), 9(3), 1823. https://doi.org/10.3991/ijim.v9i3.4420

Falsetti, M. C., \& Rodríguez, M. A. (2005). A proposal for improving students' mathematical attitude based on mathematical modelling. Teaching Mathematics and Its Applications, 24(1), 14-28. https:// doi.org/10.1093/teamat/hrh015

Fathi, H., Ebrahimzadeh, M. A., Charati, J. Y., Rostamnezhad, M., \& Shelimaki, A. B. (2017). Knowledge, attitude, and practice of students, faculty members, and staff in Mazandaran university of medical sciences about health issues in Quran and Islam. In $J$ Mazandaran Univ Med Sci. Retrieved from https://www.researchgate.net/publication/314261399

Garrett, T., The, S., Interaction, C., \& Case, A. (2015). Student-centered and teachercentered classroom management: A case study of three elementary teachers. Journal of Classroom Interaction, 43(1), 34-47. Retrieved from https://www.jstor.org/stable/23869529

Gomez Martin, M. A., Gomez Martin, P. P., \& Gonzalez Calero, P. A. (2007). Active Learning in Interactive Simulations. Inteligencia Artificial, Revista Iberoamericana de Inteligencia Artificial, 11(33), 25-36. https://doi.org/10.4114/ia.v11i33.916

Hammawa, Y. M., \& Hashim, N. B. (2016). Women Entrepreneurs' Spirituality in Business Based on Al-Quran and Sunnah: An ethico-metaphysical dimension. IOSR Journal of Business and Management (IOSR-JBM), 18(6), 37-40. https://doi.org/10.9790/487X-1806023740

Herdiansyah, H., Jokopitoyo, T., \& Munir, A. (2016). Environmental Awareness to Realizing Green Islamic Boarding School (Eco-Pesantren) In Indonesia. IOP Conference Series: Earth and Environmental Science, 30(1), 1-6. https://doi.org/10.1088/1755-1315/30/1/012017

Hixon, L. (2003). The heart of the Qur' an : an introduction to Islamic spirituality. United States, North Beauregard Street: Quest Books.

Hodson, D., \& Hodson, J. (1998). From constructivism to social constructivism : a Vygotskian perspective on teaching and learning science. School Science Review, 
79(289), 33-41. Retrieved from https://eric.ed.gov/?id=EJ570956

Hudhana, W. D. (2015). Islamic Values Reinforcement to Overcome Moral Degradation. International Conference on Education, 1-7. Retrieved from https://umpwr.ac.id/prosiding/index.php/ice/article/view/144

Huisman, J., \& Tight, M. (2015). Theory and Method in Higher Education Research. London, UK: Emerald Group Publishing.

Inglis, M., \& Alcock, L. (2012). Expert and Novice Approaches to Reading Mathematical Proofs. Journal for Research in Mathematics Education, 43(4), 358-390. https:// doi.org/10.5951/jresematheduc.43.4.0358

Jefferson, M., \& Anderson, M. (2017). Transforming schools: Creativity, critical reflection, communication, collaboration. London, UK: Bloomsbury Publishing.

John, P. D. (2006). Lesson planning and the student teacher: Re-thinking the dominant model. Journal of Curriculum Studies, 38(4), 483-498. https://doi.org/10.1080/00220270500363620

Kabir, A. I. A. (2013). The Qur' ānic Approach to the Inculcation of Moral Values: Patterns for Teacher Education. QURANICA, International Journal of Quranic Research, 5(2), 15-32. Retrieved from http://mjs.um.edu.my/index.php/quranica/article/view/5186

Karakas, F., Manisaligil, A., \& Sarigollu, E. (2015). Management learning at the speed of life: Designing reflective, creative, and collaborative spaces for millenials. The International Journal of Management Education, 13(3), 237-248. https://doi.org/10.1016/j.ijme.2015.07.001

Kasim, T. S. A. T., \& Yusoff, Y. M. (2014). Active Teaching Methods: Personal Experience of Integrating Spiritual and Moral Values. Religious Education, 109(5), 554-570. https://doi.org/10.1080/00344087.2014.956560

Kim, H. Y. (2015). Statistical notes for clinical researchers: post-hoc multiple comparisons. Restorative Dentistry \& Endodontics, 40(2), 172-176. https://doi.org/10.5395/rde.2015.40.2.172

Kong, S. C., Looi, C. K., Chan, T. W., \& Huang, R. (2017). Teacher development in Singapore, Hong Kong, Taiwan, and Beijing for e-Learning in school education. Journal of Computers in Education, 4(1), 5-25. https://doi.org/10.1007/s40692-0160062-5

Laskier, M., \& Lev, Y. (2011). The convergence of Judaism and Islam: Religious, scientific, and cultural dimensions. Gainesville, Florida: University Press of Florida.

Lazaraton, A., \& Taylor, L. (2007). Qualitative Research Methods in Language Test Development and Validation. In Language Testing Reconsidered (pp. 113-130). Ottawa, Canada: University of Ottawa Press.

Lee, J., Lim, C., \& Kim, H. (2017). Development of an instructional design model for flipped learning in higher education. Educational Technology Research and Development, 65(2), 427-453. https:// doi.org/10.1007/s11423-016-9502-1

MacLeod, J., Yang, H. H., Zhu, S., \& Li, Y. (2018). Understanding students' preferences toward the smart classroom learning environment: Development and validation of an instrument. Computers \& Education, 122, 80-91. https://doi.org/10.1016/j.compedu.2018.03.015

Moder, K. (2010). Alternatives to F-Test in One Way ANOVA in case of heterogeneity of variances (a simulation study). Psychological Test and Assessment Modeling, 52(4), 343-353. Retrieved from https:// psycnet.apa.org/record/2011-02815-001

Mohamad, S., Kulap, M., \& Hamdiyah, L. M. (2018). Historical Education in The Process of Nation Character Building of Indonesia. International Journal of Multicultural and Multireligious Understanding, https://doi.org/10.18415/ijmmu.v5i5.443 
Moon, B., Mayes, A., \& Hutchinson, S. (2002). Teaching, Learning and the Curriculum in Secondary Schools. London, UK: Routledge.

Mtebe, J. S., \& Kissaka, M. M. (2015). Deployment and Adoption Strategy of Cloud Computing for Blended Learning in Higher Education Institutions in Sub-Saharan Africa. In Handbook of Research on Educational Technology Integration and Active Learning (pp. 395-408). Hershey, USA: IGI Global.

Mueller, R. M., Lambert, M. J., \& Burlingame, G. M. (1998). Construct validity of the outcome questionnaire: A confirmatory factor analysis. Journal of Personality Assessment, 70(2), 248-262. https://doi.org/10.1207/s15327752jpa7002_5

Mustaqimah, R. (2019). The Influence of Intelligence Quotient (IQ), Self Efficacy and Self Regulated Learning on the Ability to Memorize Al-Qur'an. Didaktika Religia, 7(1), 119-148. Retrieved from https://jurnal.iainkediri.ac.id/index.php/didaktika/article/view/1552

Myers, J., \& Adams-Budde, M. (2016). Creative schools: The grassroots revolution that's transforming education. International Review of Education, 62(3), 375-378. https://doi.org/10.1007/s11159-016-9539-8

Nasr, S. (2013). Islamic spirituality: foundations. London, UK: Routledge.

Nieveen, N. (1999). Prototyping to Reach Product Quality. In Design Approaches and Tools in Education and Training (pp. 125-135). https://doi.org/10.1007/978-94-011-42557_10

Nur, M. R., \& Madkur, A. (2014). Teachers'voices on The 2013 Curriculum for English Instructional Activities. IJEE (Indonesian Journal of English Education), 1(2), 119-134. https://doi.org/10.15408/ijee.v1i2.1340

Nurdyansyah, M., Masitoh, S., \& Bachri, B. (2018). Problem Solving Model with Integration Pattern: Student's Problem Solving Capability. Proceedings of the 1st International Conference on Education Innovation (ICEI 2017). https://doi.org/10.2991/icei-17.2018.67

Owen, E., \& Sweller, J. (1989). Should Problem Solving Be Used as a Learning Device in Mathematics? Journal for Research in Mathematics Education, 20(3), 322-328. https://doi.org/10.2307/749520

Park, Y., \& Jo, I. H. (2015). Development of the learning analytics dashboard to support students' learning performance. Journal of Universal Computer Science, 21(1), 110$133 . \quad$ Retrieved from http://www.jucs.org/jucs_21_1/development_of_the_learning/jucs_21_01_0110_ 0133_park.pdf

Posamentier, A., Jaye, D., \& Krulik, S. (2007). Exemplary Practices for Secondary Math Teachers. North Beauregard Street, United States: Alexandria.

Purnamaningwulan, R. A. (2019). Pre-Service Teachers' Reflective Practices in Implementation the Scientific Aproach of 2013 Curriculum. International Journal of Indonesian Education and Teaching, 3(2), 157-168. https://doi.org/10.24071/ijiet.2019.030203

Retnawati, H. (2016). Proving content validity of self-regulated learning scale (The comparison of Aiken index and expanded Gregory index). Research and Evaluation in Education, 2(2), 155-164. https://doi.org/10.21831/reid.v2i2.11029

Retnawati, H., Hadi, S., \& Nugraha, A. C. (2016). Vocational High School Teachers' Difficulties in Implementing the Assessment in Curriculum 2013 in Yogyakarta Province of Indonesia. International Journal of Instruction, 9(1), 33-48. https://doi.org/10.12973/iji.2016.914a

Richey, R. C., \& Klein, J. D. (2014). Design and Development Research. In Handbook of Research on Educational Communications and Technology (pp. 141-150). New York, NY: Springer New York. 
Rumahlatu, D., Huliselan, E. K., \& Takaria, J. (2016). An analysis of the readiness and implementation of 2013 curriculum in the west part of Seram District, Maluku Province, Indonesia. International Journal of Environmental and Science Education, 11(12), 5662-5675. Retrieved from http://www.ijese.net/makale/731

Saged, A. A. G., Mohd Yusoff, M. Y. Z., Abdul Latif, F., Hilmi, S. M., Al-Rahmi, W. M., Al-Samman, A., ... Zeki, A. M. (2018). Impact of Quran in Treatment of the Psychological Disorder and Spiritual Illness. Journal of Religion and Health, 1-14. https://doi.org/10.1007/s10943-018-0572-8

Sitopu, F., Saragih, S., \& Hasratuddin. (2019). Development of Learning Devices Based on Problem Based Learning Model to Improve Mathematical Communication Skills. Proceedings of the 4th Annual International Seminar on Transformative Education and Educational Leadership (AISTEEL 2019). https://doi.org/10.2991/aisteel19.2019.120

Sulastri, K., Rintayati, P., \& Sarwono, S. (2019). Improving Higher Order Thinking Skills and Students' Learning Interest through Problem-Based Learning Model on Literacy. Proceedings of the Third International Conference of Arts, Language and Culture (ICALC 2018), 346-352. https://doi.org/10.2991/icalc-18.2019.49

Sulistyarini, S., Utami, T., \& Hasmika, H. (2019). Project Citizen Model as Character Education Strengthening. JETL (Journal Of Education, Teaching and Learning), 4(1), 233-237. https://doi.org/10.26737/jetl.v4i1.1023

Sumarmo, U., Kusnadi, A., \& Maya, R. (2018). Mathematical Critical Thinking Ability. Journal of Educational Experts, 1(2), 69-80. https://doi.org/10.XXXXX/jee.vXiX.XX$\mathrm{XX}$

Thiagarajan, Sivasailam, I. M. (1974). Instructional Development for Training Teachers of Exceptional Children: A Sourcebook. Bloomington, Indiana Univ: Center for Innovation.

Ubaidah, N., \& Aminudin, M. (2019). Development of learning tools: Learning constructivist mathematics to improve creative thinking ability. Journal of Physics: Conference Series, 1188(1), 1-8. https://doi.org/10.1088/1742-6596/1188/1/012071

Wahyudin, A. Y., \& Sukyadi, D. (2015). A Closer Look at the Implementation of the Curriculum 2013 in Indonesia: Should the Scientific Approach Be Used in EFL Classroom? Rangsit Journal of Educational Studies, 2(2), 56-70. https:// doi.org/10.14456/rjes.2015.11

Washburn, J. W. (1992). Teaching Difficult Vocabulary in Reading In Partial Fulfillment of the Requirements for the Degree Master of Arts in TESOL. La Mirada, California: Biola University.

Widoyoko, E. (2000). Evaluasi Program Pembelajaran [Evaluation of learning programs]. Yogyakarta, Indonesia: Pustaka Pelajar.

Winarso, W. (2018). Authentic assessment for academic performance: study on the attitudes, skills, and knowledge of grade 8 mathematics students. Malikussaleh Journal of Mathematics Learning (MJML), 1(1), 1-8. https://doi.org/10.29103/mjml.v1i1.579 


\section{Biographies}

\section{Widodo Winarso}

Widodo Winarso is an assistant professor at the Department of Mathematics Education, Institut Agama Islam Negeri Syekh Nurjati Cirebon-Indonesia. He is a Ph.D Student in Islamic Education Psychology from Muhammadiyah University of Yogyakarta, Indonesia. His research interests are in educational psychology, mathematical psychology, cognitive psychology, organizational behavior and interdisciplinary research.

\section{Sirojudin Wahid}

Sirojudin Wahid is a senior lecturer at the Department of Mathematics Education, Institut Agama Islam Negeri Syekh Nurjati Cirebon-Indonesia. He teaches mathematics learning media and Kapita Selekta [school mathematics]. His research interests are in mathematics education integrated science and islamic mathematics. 